\title{
A step further in the discovery of phthalein derivatives as thymidylate synthase inhibitors
}

\author{
Samuele Calò, ${ }^{a}$ Donatella Tondi, ${ }^{a}$ Alberto Venturelli, ${ }^{a}$ Stefania Ferrari, ${ }^{a}$ Piergiorgio \\ Pecorari, ${ }^{a}$ Marcella Rinaldi, ${ }^{a}$ Stefano Ghelli, ${ }^{\mathrm{b}}$ and M. Paola Costi*, ${ }^{, a}$ \\ ${ }^{a}$ Dipartimento di Scienze Farmaceutiche, Università degli Studi di Modena e Reggio Emilia, Via \\ Campi 183, 41100 Modena, Italy \\ ${ }^{b}$ Spinlab s.r.l., Via Tamagno 3, 42048 Rubiera (RE), Italy \\ E-mail: costimp@unimore.it
}

\begin{abstract}
In honor of Professor Vincenzo Tortorella in the occasion of his "Fuori Ruolo" status
(received 30 Jan 04; accepted 27 May 04; published on the web 28 May 04)
\end{abstract}

\begin{abstract}
Phenolphthalein (Pth) was discovered as a low micromolar inhibitor of the enzyme Thymidylate Synthase (TS), an important target for anticancer chemotherapy. In the present work, a new series of Pth derivatives have been designed and synthesized. All the compounds have been characterized through NMR techniques. A set of twelve Pth derivatives has been tested against three TS enzymes and their bio-profiles obtained. The bio-profiling studies suggest that the inhibitory potency of the compounds has been improved of about fifty times against Lactobacillus casei TS (LcTS) and five times against humant TS (hTS) with respect to the lead. The most active compound shows an inhibition constant $\left(\mathrm{K}_{\mathrm{i}}\right)$ of $70 \mathrm{nM}$ against Escherichia coli TS (EcTS).
\end{abstract}

Keywords: 3H-Isobenzofuran-1-one derivatives, enzyme inhibition, thymidylate synthase

\section{Introduction}

Thymidylate synthase (TS) catalyzes the methylation reaction of 2'-deoxyuridine-5'monophosphate (dUMP) to $2^{\prime}$-deoxythymidine-5'-monophosphate (dTMP). This is a key step in the folate-dependent pathway that involves enzymes such as Dihydrofolate reductase (DHFR), Serinehydroxymethyl-transferase (SHMT), Glycinamide-ribonucleotide transformylase (GARTF) and Amino-imidazolecarboxamide-ribonucleotide formyl transferase (AICARTF). ${ }^{1}$ Each of these steps is essential for the correct cell proliferation process. TS and DHFR are two of the most known target in anticancer chemotherapy and only recently TS has been regarded as potential target for anti-infectious diseases. ${ }^{2-12}$ In anticancer chemotherapy, TS is strongly inhibited by the nucleotide substrate (dUMP) analog, 5-fluoro-2'-deoxyuridine monophosphate (FdUMP) and the folate substrate (mTHF, 5,10-methylenetetrahydrofolate) analogs, such as 
CB3717 and ZD1694, at present in clinical practice (Figure 1). Other folate analogs are currently in clinical trials. ${ }^{13,14}$<smiles>NC(=O)C1C2CN(c3ccc(C(=O)NC(CCC(=O)O)C(=O)O)cc3)CC2CN1/C(N)=N\C(N)N</smiles>

mTHF<smiles>Cc1nc2ccc(CN(C)c3ccc(C(=O)NC(CCC(=O)O)C(=O)O)s3)cc2c(=O)[nH]1</smiles>

ZD1694<smiles>C#CCN(Cc1ccc2nc(N)[nH]c(=O)c2c1)c1ccc(C(=O)NC(CCC(=O)O)C(=O)O)cc1</smiles>

CB3717

\section{Figure 1}

However severe resistance problems are encountered after prolonged administration of these drugs, owing to their high structural similarity to the folate cofactor. Many of the resistance mechanisms are related the fact that folate analogs drugs are metabolized through the same pathway that folate does. To prevent resistance it can be useful to design new chemical entities dissimilar from the substrate, but still able to inhibit the enzyme. Recently, new series of compounds, unrelated to mTHF, with TS inhibitory activity were discovered. ${ }^{2,7-9}$ In particular phenolphthalein (Pth, Figure 2), a well-known $\mathrm{pH}$ indicator, was identified in a pioneering work of structure-based drug design, in which an automated docking procedure (DOCK 3.0) was applied to the virtual screening of 55,313 compounds taken from the Fine Chemical Directory (FCD), against the three-dimensional structure of LcTS. ${ }^{2}$ The compound shows an inhibition constant $\left(\mathrm{K}_{\mathrm{i}}\right)$ of $4.4 \mu \mathrm{M}$ against LcTS. ${ }^{2}$ With the aim to understand the structural basis of the interaction between Pth and LcTS, and to develop higher affinity ligands, the x-ray crystal structure of the binary complex of Pth with the enzyme LcTS was obtained. ${ }^{2}$<smiles>O=C1OC(c2ccc(O)cc2)(c2ccc(O)cc2)c2ccccc21</smiles>

Pth<smiles>O=C1OC(c2ccc(O)c(Cl)c2)(c2ccc(O)c(Cl)c2)c2cccc3cccc1c23</smiles>

$\alpha 156$

\section{Figure 2}


Pth represents a lead, structurally unrelated to the classical folate analog inhibitors, which could be developed in selective and more potent leads. We studied, previously, through NMR techniques, the conformational properties of a few structural analogs of Pth in order to identify the molecular state involved in the enzyme interaction. ${ }^{15}$ A superior homologous molecule, phenolnaphthalein, was also considered and many derivatives were designed and synthesized. ${ }^{7,8}$ Phenolnaphthaleins, such as $\mathbf{\alpha 1 5 6}$ (Figure 2), show an interesting specificity profile, owing to their attitude to preferably inhibit non-human TS enzymes (Table 2). ${ }^{7,12}$

Concerning Pth, in alkaline medium it exists in different molecular states involved in a complex equilibrium including the open forms responsible of its properties as a $\mathrm{pH}$ indicator (see Results and Discussion). We recently selected some commercially available sulfonic acid derivatives (Table 1, compounds 4-6) ${ }^{16}$ that can be considered stable bioisosteric analogs of the Pth open form.

Analyzing the $\mathrm{IC}_{50}$ values of compounds 1, 2 and 3 together with the related sulfonic acids analogs 4, 5 and 6, we noted that the couples 1/4, 2/5, 3/6 show approximately the same $\mathrm{IC}_{50}$ values, thus suggesting that the open form of Pth and its derivatives may maintain some inhibitor activity against the enzyme LcTS.

Table 1. Comparison of $\mathrm{IC}_{50}$ values against LcTs for phenolphthalein derivatives (1-3) and structurally related sulfonic acid derivatives (4-6)

Code $\quad \mathrm{IC}_{50}(\mu \mathrm{M})$ Code

In the present work we have designed and synthesized a new set of phenolphthalein derivatives to develop structure-activity-relationship (SAR) studies in a closely related series. In particular the phenol ring, and/or the benzene ring have been substituted with halogen atoms or a methyl group (Table 2, compounds 8-12). To assess the biological activity of the open form of Pth derivatives, two compounds with a benzoyl-benzoic acid structure were included in our compounds set for SAR studies. Moreover we have attempted the bioisosteric substitution of one hydroxyl functionality in Pth with the thiol functionality (thiophenol instead of phenol), but the 
product of the reaction wasn't the expected compound, in fact, 15 (Table 2) was a thio-ether only partly similar to Pth.

All the compounds have been submitted to rapid screening assay to define the in vitro biological activity profile against Lactobacillus casei TS (LcTS), Escherichia coli TS (EcTS) and human TS (hTS).

\section{Results and Discussion}

\section{Chemistry}

Compounds 7-12 were prepared by heating the substituted phthalic anhydrides with the appropriate phenols in the presence of an acid catalyst (sulphuric acid), as outlined in Scheme 1.

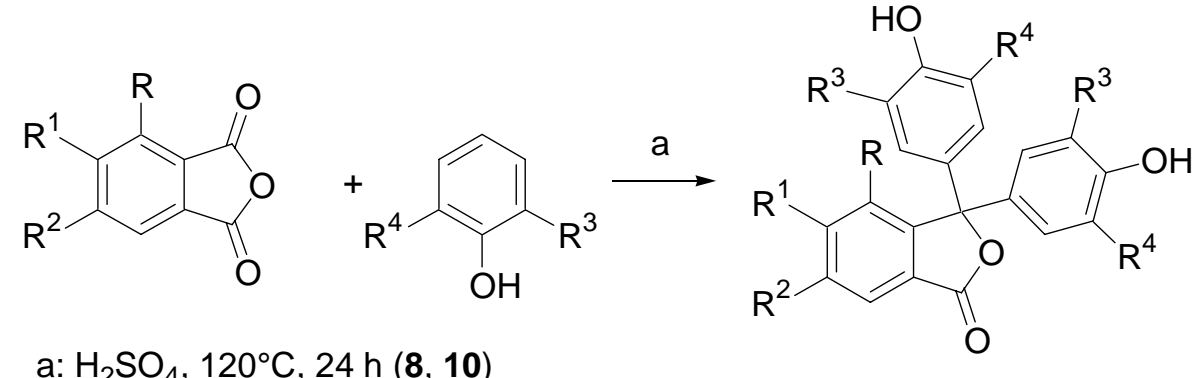

$$
\begin{aligned}
\text { a: } \mathrm{H}_{2} \mathrm{SO}_{4}, 120^{\circ} \mathrm{C}, 24 \mathrm{~h}(\mathbf{8}, \mathbf{1 0}) \\
\mathrm{H}_{2} \mathrm{SO}_{4}, 120^{\circ} \mathrm{C}, 48 \mathrm{~h}(\mathbf{7}, \mathbf{9}, \mathbf{1 1}) \\
\mathrm{H}_{2} \mathrm{SO}_{4}, 80^{\circ} \mathrm{C}, 72 \mathrm{~h} \mathrm{(12)}
\end{aligned}
$$

\section{Compounds 7-12}

\begin{tabular}{c|ccccc} 
& $\mathrm{R}$ & $\mathrm{R}^{1}$ & $\mathrm{R}^{2}$ & $\mathrm{R}^{3}$ & $\mathrm{R}^{4}$ \\
\hline $\mathbf{7}$ & $\mathrm{H}$ & $\mathrm{H}$ & $\mathrm{H}$ & $\mathrm{Cl}$ & $\mathrm{Cl}$ \\
$\mathbf{8}$ & $\mathrm{F}$ & $\mathrm{H}$ & $\mathrm{H}$ & $\mathrm{H}$ & $\mathrm{H}$ \\
$\mathbf{9}$ & $\mathrm{F}$ & $\mathrm{H}$ & $\mathrm{H}$ & $\mathrm{Cl}$ & $\mathrm{H}$ \\
$\mathbf{1 0}$ & $\mathrm{H}$ & $\mathrm{Cl}$ & $\mathrm{Cl}$ & $\mathrm{H}$ & $\mathrm{H}$ \\
$\mathbf{1 1}$ & $\mathrm{H}$ & $\mathrm{Cl}$ & $\mathrm{Cl}$ & $\mathrm{Cl}$ & $\mathrm{H}$ \\
$\mathbf{1 2}$ & $\mathrm{H}$ & $\mathrm{CH}_{3}$ & $\mathrm{H}$ & $\mathrm{H}$ & $\mathrm{H}$
\end{tabular}

\section{Scheme 1}

Reaction of 3-fluoro-phthalic anhydride with phenol (compound 8) or 2-chloro-phenol (compound 9) gave a couple of positional isomers, indicated as a and b. Both the obtained mixtures showed an isomeric ratio (isomers a and b) of 4:1 (Figure 3). Compounds 8 and 9 were determined by NMR studies through mono- and bi-dimensional experiments (COSY, NOESY, HSQC and HMBC). In particular, to characterize the positional isomers, the signal corresponding to the proton positioned in para with respect to the fluorine atom was used: the chemical shift of this proton in isomer a (H-7) decreases of about $0.04 \mathrm{ppm}$ with respect to the corresponding chemical shift of the starting product whereas this decrement reaches $0.3 \mathrm{ppm}$ in isomer b (H-4). Moreover, while $\mathrm{H}-7$ shows a long range coupling with the carbonyl carbon $\mathrm{C}-1$, $\mathrm{H}-4$ shows a long range coupling with the benzylic carbon $\mathrm{C}-3$. 


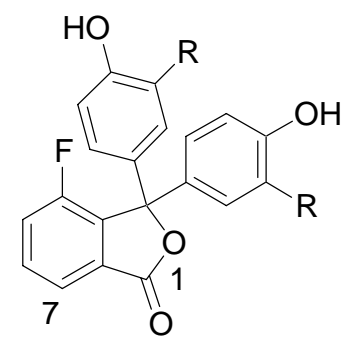

$\mathbf{8} \mathbf{a} \mathrm{R}=\mathrm{H}, \mathbf{9} \mathbf{a} \mathrm{R}=\mathrm{Cl}$

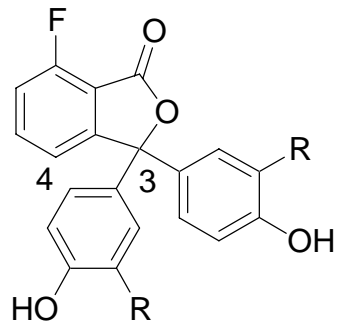

8b $R=H, 9 b R=C l$

\section{Figure 3}

The higher yield of isomer a could be explained by the formation of a more stable intermediate $\mathbf{A}$, due to an intramolecular hydrogen bond between the hemiacetalic hydroxyl group and the fluorine (Figure 4).

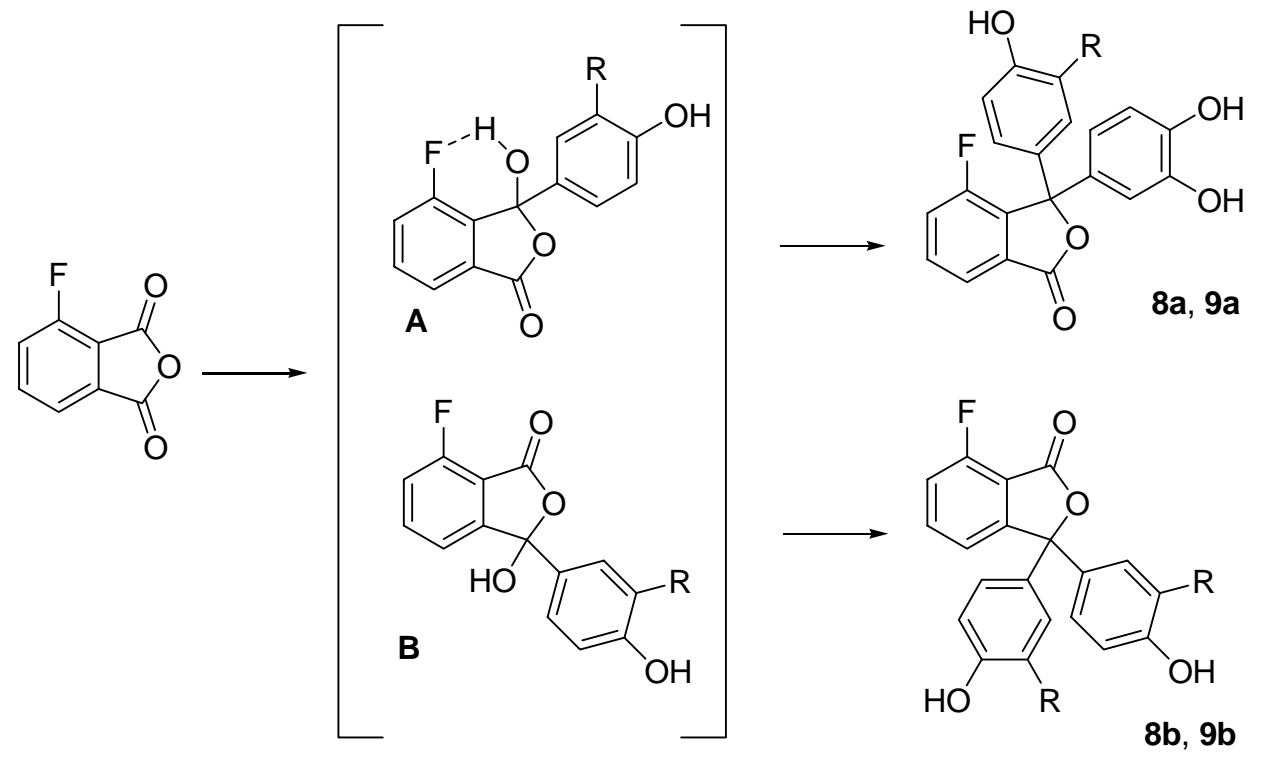

Figure 4

A further confirmation of the mentioned pattern comes by reacting 5-methyl-phthalic anhydride with phenol. The ratio between the two obtained isomers (12a, 12b) was 1:1 (Figure $5)$.<smiles>Cc1ccc2c(c1)C(c1ccc(O)cc1)(c1ccc(O)cc1)OC2=O</smiles>

$12 a$<smiles>Cc1ccc2c(c1)C(=O)OC2(c1ccc(O)cc1)c1ccc(O)cc1</smiles>

$12 b$

Figure 5 
An unsymmetrical derivative of Pth (15) was synthesized by reaction of 2-(4'hydroxybenzoyl)-benzoic acid (14), (preformed together with 13 by reaction of phthalic anhydride and phenol, at $120^{\circ} \mathrm{C}$, in presence of a $\mathrm{AlCl}_{3}$ as Lewis Acid), with thionyl chloride and 2-chloro-benzenthiol (Scheme 2). Similar thio-ethers were reported in literature. ${ }^{17,18}$<smiles>Cc1ccc(C(=O)c2ccccc2O)c(C(=O)O)c1</smiles><smiles>O=C(O)c1ccccc1C(=O)c1ccc(O)cc1</smiles>

a: $\mathrm{AlCl}_{3}$, tetrachloroethane, $120^{\circ} \mathrm{C}, 24 \mathrm{~h}$

b: $\mathrm{SOCl}_{2}, 80^{\circ} \mathrm{C}, 14 \mathrm{~h}$<smiles>Sc1ccccc1Cl</smiles>

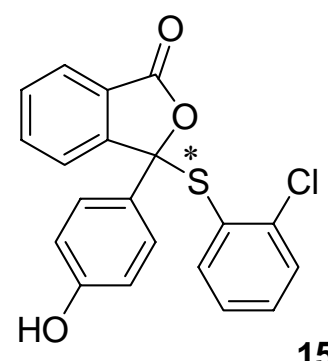

\section{Scheme 2}

\section{Bio-profiling}

All the synthesized molecules, two commercially available phenolphthalein derivatives analogous of compound 7 (compounds 2 and 3) and one previously synthesized compound (1) were tested against LcTS, EcTS, hTS enzymes. The apparent $\mathrm{K}_{\mathrm{i}}$ values are reported in Table 2.

The activity of these compounds against the model enzyme LcTS was evaluated and the observed inhibition constant ranges between $0.10 \mu \mathrm{M}$ and $10 \mu \mathrm{M}$. All compounds are competitive inhibitors of the enzyme with respect to the folate cofactor. There are two orders of magnitude between the best compound 8 and the worst one 13. In particular compounds $\mathbf{3 , 8}$ and 10 show sub-micromolar $K_{i}$ values $\left(K_{i}=0.90 \mu \mathrm{M}, 0.10 \mu \mathrm{M}\right.$ and $0.43 \mu \mathrm{M}$, respectively); the remaining compounds show $\mathrm{K}_{\mathrm{i}}$ values in the micromolar range. Therefore the inhibition constant of the best compounds is about fifty times lower than the starting hit, Pth, and similar to that of the reference compound, CB3717.

The $\mathrm{K}_{\mathrm{i}}$ values against EcTS are between $70 \mathrm{nM}$ and $29 \mu \mathrm{M}$; about three orders of magnitude between the $K_{i}$ of the best 12 and the worst 13 compounds. In particular compounds 8, 10 and 12 show $K_{i}$ values in the sub-micromolar range $(0.07-0.15 \mu \mathrm{M}) ; K_{i}$ for compounds $\mathbf{1}, \mathbf{3 ,}, \mathbf{9}, \mathbf{1 1}, 14$, and 15 ranged between $0.78-4.97 \mu \mathrm{M}$. The inhibition activity of compound 12 against EcTS is similar to the reference compound, CB3717. Compounds 7 and 13 have $\mathrm{K}_{\mathrm{i}}$ around $30 \mu \mathrm{M}$.

The best inhibition constant against hTS is $0.25 \mu \mathrm{M}$ (compound 12). Compound 13 shows the worst activity with a $\mathrm{K}_{\mathrm{i}}$ of $60 \mu \mathrm{M}$. In general the inhibition activity towards hTS has been 
improved five times in comparison with the starting hit Pth, but it is still about ten times worst than that of the reference compound, CB3717.

It is noteworthy that compounds $\mathbf{1 3}$ and $\mathbf{1 4}$ that are apparently structurally unrelated to the phthalein derivatives maintain a moderate inhibitory activity against all the enzymes. Compound 14 with a $K_{i}$ of $4.83 \mu \mathrm{M}$ is slightly better than 13 that show a $K_{i}$ value of $10 \mu \mathrm{M}$ towards LcTS.

The activity of compounds $\mathbf{1 3}$ and $\mathbf{1 4}$ deserve a focused analysis. From our ongoing study on the acid-base solution equilibrium studies on the phenolphthalein derivatives it results that at $\mathrm{pH}$ 7.4 some of the molecules bearing phenolphthalein-like structure exist also in open forms, $\mathrm{m} 5$ and m6, of phthalic acid (Figure 6). ${ }^{19}$ The proposed equilibrium can include at least six species corresponding to different molecular states (m1-m6). Being the known pKa values of Pth of 8.60 and 9.57, in the assay condition ( $\mathrm{pH} \mathrm{7.4)} \mathrm{the} \mathrm{equilibrium} \mathrm{is} \mathrm{approximately} \mathrm{established} \mathrm{for} \mathrm{the}$ states $\mathrm{m} 1, \mathrm{~m} 2$, and $\mathrm{m} 5$ and is ruled by the appropriate equilibrium constant; the bioactive molecular state, i.e. the preferred form with the highest affinity towards the TS enzymes, is unknown.

Compound 15 was tested as a racemic mixture and show moderate/low affinity towards the three enzymes.

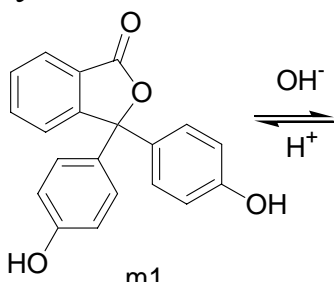

m1
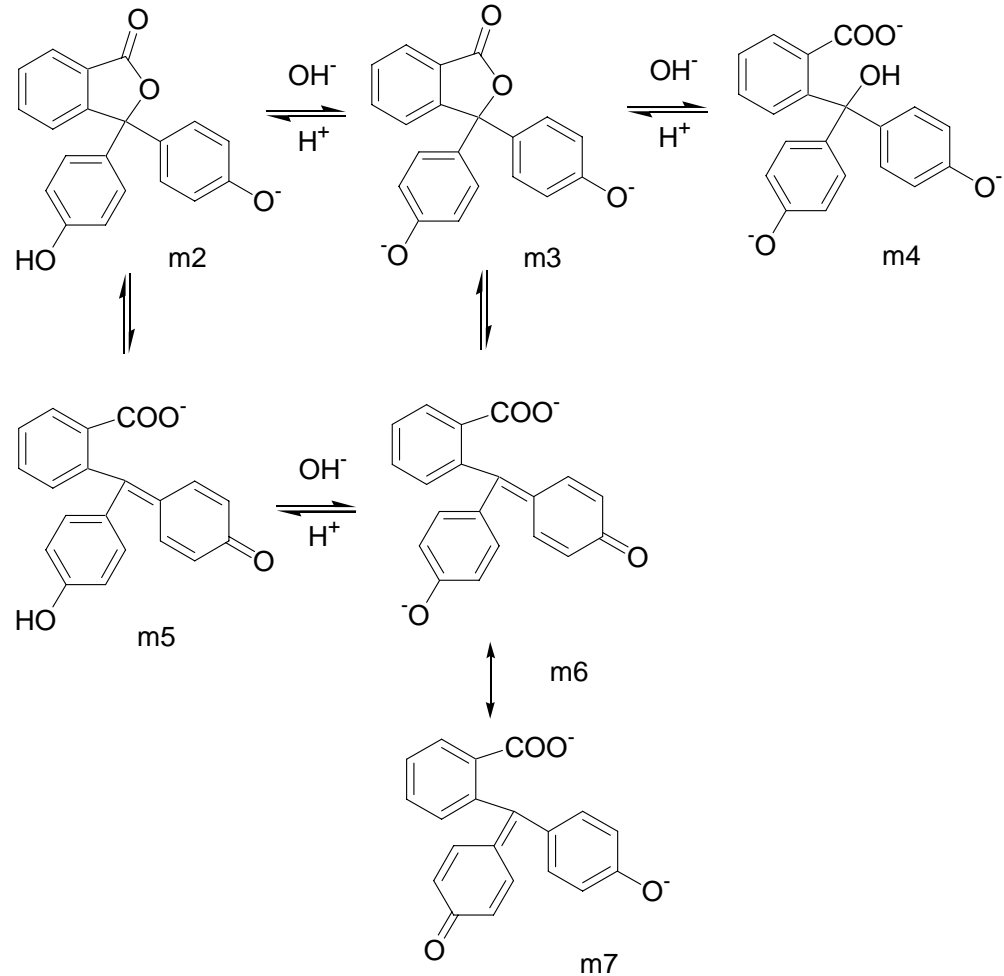

\section{Figure 6}

\section{Structure-based structure-activity relationship}

The structural modifications we have introduced on Pth were designed following SAR analysis based on the hit structure. The availability of the x-ray crystal structure of the binary complex LcTS-Pth allowed us to analyze the bio-profile of Pth and its derivatives through visual 
inspection of the available crystallographic complex. Each molecule was rigidly modeled in the active site based on Pth crystallographic orientation.

Pth in complex with LcTS forms three hydrogen bonds with R23, E60 and D221 directly or water-mediated. It also interacts thought van der Waals contacts with I81, W82, E84, W85, V314 and V316 (Figure 7). ${ }^{2}$

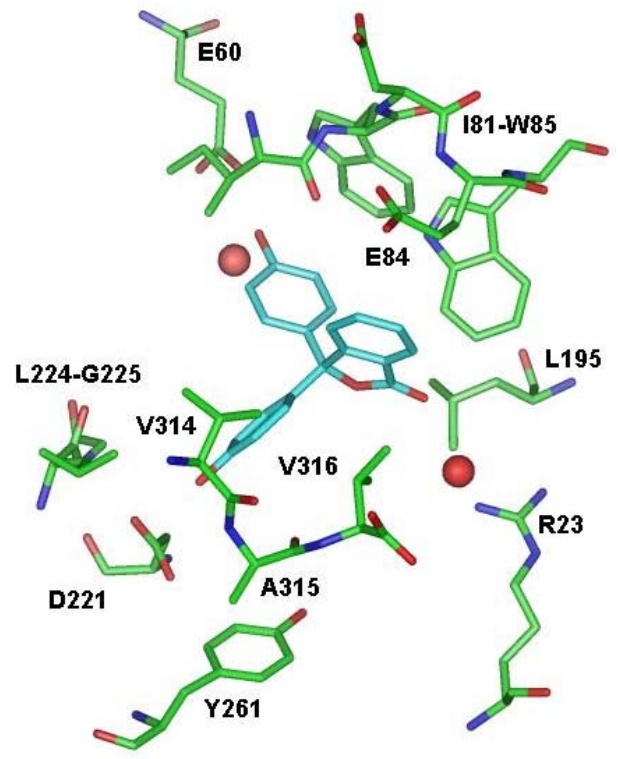

Figure 7. Detail of the crystal structure of the binary complex LcTS-Pth. Binding mode of Pth in LcTS.

A fluorine atom in position 4 or 7 (compounds 8 and 9) would not form additive interaction being easily accommodated inside the binding site of Pth. In position 4 it could interact with the benzene ring of W85 and with a water molecule present in the binding site. This additional interaction can account for the one-fold increasing in the binding energy $\left(\mathrm{K}_{\mathrm{i}}\right)$ with respect to Pth. Two chlorine atoms in position 5 and 6 (compounds 10 and 11) or a methyl in position 5 or 6 (compound 12) could interact with E84, V314 and V316 of the "small domain" through hydrophobic interaction. However small adaptations of residue E84 are needed. With the replacement of a phenol with a 2-chloro-phenylthioether (compound 15) the carbon atom C-3 becomes chiral. We noticed that in the case of compound 15 one of the hydrogen bond with E60 or D221 would be lost since the compound has one less hydroxyl group compared to Pth, but the $\mathrm{K}_{\mathrm{i}}$ remains in the same order indicating that the new interaction of the chlorine atom can counterbalance the H-bond lost. In particular one chlorine atom on each phenol ring (compounds 1, 9 and 11) would allow the interaction of one phenol ring with I81 or W82 and W85 and of the other phenol ring with D221, L224, G225 or V314, A315 and V316. Two halogen atoms on each phenol ring (compounds 2, 3 and 7) would allow the interaction also with L224, G225 and A315 and would increase the van der Waals contacts with I81, W82, E84, W85, D221, V314 and V316. Small adaptations of these residues are needed in particular in the case of tetraiodophenolphthalein (3). These additional van der Waals contacts due to the halogen on the phenol ring can modulate the SAR depending on the strength of the electronic effect of the 
halogen introduced. In particular effect on the $\mathrm{pKa}$ of the phenyl hydroxyl can be taken in consideration.

Pth open form analogs (compounds 13 and 14) would interact with I81, E84, W85, V314 and V316 through the benzene ring. The carboxyl acid group would form a water-mediated hydrogen bond with R23. The phenol ring would interact with R23, W85 and L195. An hydroxyl group in ortho (compound 13) would form a water-mediated hydrogen bond with E60 while an hydroxyl group in para (compound 14) would form an hydrogen bond with Y261 and van der Waals contacts with D221.

From these results it is clear that the little structural modifications introduced in the hit molecule, do not deeply change the pattern of interactions with the enzyme. Compounds 7, 9, 13, 14 and 15 have the same degree of inhibitory potency of Pth $\left(K_{i}\right.$ in the range 1-10 $\left.\mu \mathrm{M}\right)$ even if compounds 13, 14 and 15 would loose one hydrogen bond interaction with the enzyme. Thus, some compensation in terms of binding energy should be present. Other compounds, in particular 3, 8, and 10, show increased activity, up to fifty times with respect to Pth. However this is not easily explainable only on the base of a rigid visual analysis of the ligand-enzyme interactions.

Table 2. Biological activity of compounds 1-3, 7-15, Pth, CB3717 and $\alpha 156$ towards LcTS, EcTS, hTS $\left(\mathrm{K}_{\mathrm{i}}\right.$ in $\left.\mu \mathrm{M}\right)$

\begin{tabular}{|c|c|c|c|c|c|c|c|c|c|}
\hline Code & Compounds & \multicolumn{3}{|c|}{ Enzyme } & Code & Compounds & \multicolumn{3}{|c|}{ Enzyme } \\
\hline & & LcTS & EcTS & hTS & & & LcTS & EcTS & hTS \\
\hline Pth & & 4.70 & - & 1.2 & 9 & & 8.97 & 0.97 & 1.57 \\
\hline$\alpha 156$ & & 0.70 & 0.60 & 30 & 10 & & 0.43 & 0.11 & 0.38 \\
\hline CB3717 & & 0.06 & 0.06 & 0.03 & 11 & & 1.43 & 1.50 & 1.03 \\
\hline
\end{tabular}


Table 2. Continued

(1.51 2.33

\section{Conclusions}

We have explored the possibility to improve the bio-profiling activity of Pth as inhibitor of TS enzymes. We selected thirteen compounds for SAR studies; among them, nine new compounds have been synthesized and in detail characterized through NMR techniques. All the compounds have been tested against three TS enzymes and their bio-profiles have been obtained.

All these compounds share with Pth the same bio-profile, being active against all the three enzymes. Compounds 8, 10 and 12 are the most active ones showing sub-micromolar $\mathrm{K}_{\mathrm{i}}$ values. The inhibitory potency of Pth has been improved of about fifty times against LcTS and five times against hTS. 


\section{Experimental Section}

General Procedures. Melting points were determined on a Buchi 510 capillary melting points apparatus and are uncorrected. Analyses were within $+/-0.4 \%$ of theoretical values. TLC on silica gel plates was used to check product purity. Silica gel 60 (Merck: 70-120 mesh) was used for column chromatography. The structure was determined by NMR studies through monodimensional experiments, structure of compounds 8, 9, 12 were resolved with bidimesional experiment (COSY, NOESY, HSQC and HMBC).

All the compounds were dissolvend in DMSO- $d_{6}$, one dimensional experiments were recorded on a BRUKER FT-NMR DPX200 spectromer operating at 4.7 Tesla, all 2D spectra were acquired on a BRUKER FT-NMR AVANCE400 spectromer operating at 9.4 Tesla.

2D-COSY, 2D-HSQC and 2D-HMBC spectra were recorded using respectively the sequence cosygpqf, hsqcetgp and hmbcgplpndqf.

The structures of all the compounds were consistent with their analytical data.

(n)

\section{General method for preparation phtalein derivatives 7-12}

A mixture of the substituted phthalic anhydride $(0.01 \mathrm{~mol})$ and the appropriate phenol $(0.03 \mathrm{~mol})$ in acid conditions (sulphuric acid 96\%, 25-30 drops) was heated at $115-125^{\circ} \mathrm{C}$ for $24 \mathrm{~h}(\mathbf{8}, \mathbf{1 0})$ and for $48 \mathrm{~h}(7,9,11)$ with stirring, while for compound 12 starting materials were heated at $80^{\circ}$ $\mathrm{C}$ for $48 \mathrm{~h}$. After cooling the mixture was poured into ice and stirred for 30'. The crude mixture undergoes different work up.

3,3-Bis-(3,5-dichloro-4-hydroxy-phenyl)-3H-isobenzofuran-1-one (7). Compound 7 was purified through flash-chromatography (chloroform/methanol 95/5 v.v). Yield 7.8\%; mp $210^{\circ} \mathrm{C}$. $\mathrm{C}_{20} \mathrm{H}_{10} \mathrm{Cl}_{4} \mathrm{O}_{4}$ calc. C $52.6 \% \mathrm{H} 2.2 \%$; found: $\mathrm{C} 52.2 \%, \mathrm{H} 2.0 \%$. ${ }^{1} \mathrm{H}$ NMR (DMSO $\delta 2.6 \mathrm{ppm}$ ) 7.37 (s, 4H, H-5), 7.81 (dt, 1H, H-3, J = 7.6, $0.8 \mathrm{~Hz}$ ), 8.00 (dt, 1H, H-2, J = 7.4, $0.5 \mathrm{~Hz}$ ), 8.04 
(dd, 1H, H-4, J = 7.6, $0.8 \mathrm{~Hz}), 8.18(\mathrm{dd}, 1 \mathrm{H}, \mathrm{H}-1, J=7.4,0.5 \mathrm{~Hz}), 10.68$ (s, 2H,H-6, J= 7.4, $0.5 \mathrm{~Hz}$ ).

4-Fluoro-3,3-bis-(4-hydroxy-phenyl)-3H-isobenzofuran-1-one (8a and 8 b). The pair of positional isomers 8 were obtained in $4: 1$ ratio by crystallization of the crude with dichloromethane/petroleum ether (60/80). Yield 9.3\%; mp 210-215 ${ }^{\circ} \mathrm{C} . \mathrm{C}_{20} \mathrm{H}_{13} \mathrm{FO}_{4}$ calc: $\mathrm{C}$ $71.4 \%$ H $3.9 \%$; found: $\mathrm{C} 71.0 \%$, H $3.9 \%$. The mixture of the isomers was characterized by NMR Compound (8a) ${ }^{1} \mathrm{H}$ NMR (DMSO $\delta 2.6$ ppm) 6.87 (d, 4H, H-11, J=8.0 Hz), 7.14 (d, 4H, $\mathrm{H}-12, J=8.0 \mathrm{~Hz}), 7.78$ (t, 1H, H-2, $\left.J_{H-F, H-H}=9.2,7.6 \mathrm{~Hz}\right), 7.85$ (m, 1H, H-3), 7.91 (d, 1H, H-4, $J=7.2 \mathrm{~Hz}$ ), 9.8 (s, 2H, H-13); ${ }^{13} \mathrm{C}$ NMR (DMSO $\left.\delta 2.6 \mathrm{ppm}\right) 92.1 \mathrm{C}-8,115.7 \mathrm{C}-10,122.7 \mathrm{C}-4$, 122.8 C-2, 129.0 C-5, 129.1 C-11, 131.2 C-9, 133.6 C-3, 138.2 C-6, 155.6 C-1 ( $\left.J_{C-F}=248 \mathrm{~Hz}\right)$, $159.1 \mathrm{C}-12$, $169.5 \mathrm{C}-7$; long range coupling ${ }^{1} \mathrm{H}-{ }^{13} \mathrm{C}$ (lrc) $\mathrm{H} 11 \mathrm{C}-9 / \mathrm{C}-11 / \mathrm{C}-12 / \mathrm{C}-10$, H10C8/C10/C11/C12, H2 C-4/C-6/C-1, H3 C-5/C-6, H4 C-2/C-6/C-7.

Compound (8b) ${ }^{1} \mathrm{H}$ NMR (DMSO $\delta 39.5$ ppm) 6.85 (d, 4H, H-5, J= 7.8 Hz), 7.17 (d, 4H, H-4, $J=7.8 \mathrm{~Hz}), 7.53\left(\mathrm{t}, 1 \mathrm{H}, \mathrm{H}-1, J_{H-F, H-H}=8.4 .7 .9 \mathrm{~Hz}\right), 7.65(\mathrm{~d}, 1 \mathrm{H}, \mathrm{H}-3, J=8.4 \mathrm{~Hz}), 7.95$ (dt, $1 \mathrm{H}$, $\left.\mathrm{H}-2, J_{H-H, H-F}=8.4,5.0 \mathrm{~Hz}\right), 9.82(\mathrm{~s}, 2 \mathrm{H}, \mathrm{H}-6)$.

3,3-Bis-(3-chloro-4-hydroxy-phenyl)-4-fluoro-3H-isobenzofuran-1-one (9a and 9 b). The pair of positional isomers 9 were obtained in $4: 1$ ratio by crystallization of the crude with dichloromethane/petroleum ether (60/80). Yield $5.0 \%$; mp 135-140 ${ }^{\circ} \mathrm{C} . \mathrm{C}_{20} \mathrm{H}_{11} \mathrm{FCl}_{2} \mathrm{O}_{4}$ calc: $\mathrm{C}$ $59.2 \%, \mathrm{H} 2.7 \%$ found: C $59.0 \% \mathrm{H} 3.0 \%$.

Compound (9a) ${ }^{1} \mathrm{H}$ NMR (DMSO $\delta 2.6$ ppm) 7.11 (d, 2H, H-6, J=8.8 Hz), 7.14 (dd, 2H, H-5, $J$ $=8.8,1.6 \mathrm{~Hz}), 7.21(\mathrm{~d}, 2 \mathrm{H}, \mathrm{H}-4, J=1.6 \mathrm{~Hz}), 7.83\left(\mathrm{t}, 1 \mathrm{H}, \mathrm{H}-1, J_{H-F, H-H}=8.0,7.9 \mathrm{~Hz}\right), 7.89(\mathrm{dt}$, $\left.1 \mathrm{H}, \mathrm{H}-2, J_{H-H, H-F}=8.0,5.0 \mathrm{~Hz}\right), 7.95(\mathrm{~d}, 1 \mathrm{H}, \mathrm{H}-3, J=8.0 \mathrm{~Hz}), 10.73(\mathrm{~s}, 2 \mathrm{H}, \mathrm{H}-7)$.

Compound (9b): ${ }^{1} \mathrm{H}$ NMR (DMSO $\delta 2.6$ ppm) 7.09 (dd, 2H, H-5, J=8.6, $1.6 \mathrm{~Hz}$ ), 7.19 (d, 2H, $\mathrm{H}-6, J=8.8 \mathrm{~Hz}$ ), 7.29 (d, 2H, H-4, $J=1.6 \mathrm{~Hz}), 7.57$ (dd, $\left.1 \mathrm{H}, \mathrm{H}-1, J_{H-F, H-H}=7.8,7.9 \mathrm{~Hz}\right), 7.79$ $(\mathrm{d}, 1 \mathrm{H}, \mathrm{H}-3, J=7.8 \mathrm{~Hz}), 8.00\left(\mathrm{dt}, 1 \mathrm{H}, \mathrm{H}-2, J_{H-H, H-F}=7.8,5.0 \mathrm{~Hz}\right)$

5,6-Dichloro-3,3-bis-(4-hydroxy-phenyl)-3H-isobenzofuran-1-one (10). Compound 10 was isolated from the crude through repeated extraction with dichloromethane. The extracts, collected and dried, were crystallizated by acetone/petroleum ether (60/80). Yield 11.2\%; mp 140-145 ${ }^{\circ} \mathrm{C} . \mathrm{C}_{20} \mathrm{H}_{12} \mathrm{Cl}_{2} \mathrm{O}_{4}$ calc: $\mathrm{C} 62.03 \% \mathrm{H} 3.12 \%$; found: $\mathrm{C} 61.8 \%, \mathrm{H} 3.06 \%{ }^{1} \mathrm{H}$ NMR (DMSO $\delta 2.6 \mathrm{ppm}) 6.85$ (d, 4H, H-4, J=8.8 Hz), 7.19 (d, 4H, H-3, J=8.8 Hz), 8.25 (s, 1H, H2), 8.27 (s, 1H, H-1), 9.75 (s, 2H, H-5).

5,6-Dichloro-3,3-bis-(3-chloro-4-hydroxy-phenyl)-3H-isobenzofuran-1-one (11). Compound 11 was isolated from the crude through repeated extraction with dichloromethane. The extracts were collected, dried and the crude were crystallized by acetone/petroleum ether $(60 / 80)$. Yield $7.3 \%$; mp 175-180 ${ }^{\circ} \mathrm{C} . \mathrm{C}_{20} \mathrm{H}_{10} \mathrm{Cl}_{4} \mathrm{O}_{4}$ calc.: C $52.7 \% \mathrm{H} 2.21 \%$; found: C $52.1 \%, \mathrm{H} 2.19 \%$; ${ }^{1} \mathrm{H}$ NMR (DMSO $\delta 2.6$ ppm) 7.08 (d, 2H, H-5, J=8.1 Hz), 7.33 (d, 2H, H-3, J=2.2 Hz), 7.45 (dd, 2H,H-4, J = 8.1, 2.2 Hz), 8.29 (s, 1H), 8.44 (s, 1H), 10.62 (s, 2H, H-6).

3,3-Bis-(4-hydroxy-phenyl)-5-methyl-3H-isobenzofuran-1-one (12a and 12b). The pair of positional isomers 12 was obtained from the crude through repeated extraction with chloroform. The extracts were collected and dried and the residue was washed with ethyl ether.

(12a) $15.2 \%$; mp 215-220 ${ }^{\circ} \mathrm{C}$; ${ }^{1} \mathrm{H}$ NMR (DMSO $\left.\delta 2.6 \mathrm{ppm}\right) 2.56\left(\mathrm{~s}, 3 \mathrm{H}, \mathrm{CH}_{3}\right), 6.85$ (d, 2H, H$11, J=8.4 \mathrm{~Hz}), 7.16(\mathrm{~d}, 2 \mathrm{H}, \mathrm{H}-10, J=8.4 \mathrm{~Hz}), 7.54$ (d, 1H, H-3, J=7.6 Hz), 7.64 (s, 1H, H-1), 
7.87 (d, 1H, H-4, J = 7.6 Hz), 9.7 (s, 2H, H-13); ${ }^{13} \mathrm{C}$ NMR (DMSO $\delta 39.5$ ppm) $22.1 \mathrm{CH}_{3}, 91.7$ C-8, 115.6 C-11, 122.6 C-1, 125.1 C-4, 27.2 C-5, 128.6 C-10, 131.7 C-9, 131.8 C-3, 146.2 C-6, 150.2 C-2, 157.9 C-12; $1 \mathrm{rc} \mathrm{H} 1 \mathrm{CH}_{3} / \mathrm{C}-8 / \mathrm{C}-3 / \mathrm{C}-5, \mathrm{H}-3 \mathrm{CH}_{3} / \mathrm{C}-5 / \mathrm{C}-1, \mathrm{H}-4 \mathrm{C}-2 / \mathrm{C}-6 / \mathrm{C}-7, \mathrm{H}-10 \mathrm{C}-$ 8/C-10/C-12, H-11 C-9/C-11; NOESY CH 3 H-1/H-3, H-11 H-10/H-13, H-10 H-1, H-3 H-4.

(12b) ${ }^{1} \mathrm{H}$ NMR (DMSO $\left.\delta 2.6 \mathrm{ppm}\right) 2.53\left(\mathrm{~s}, 3 \mathrm{H}, \mathrm{CH}_{3}\right), 6.85(\mathrm{~d}, 2 \mathrm{H}, \mathrm{H}-11, J=8.4 \mathrm{~Hz}), 7.16$ (d, $2 \mathrm{H}, \mathrm{H}-10, J=8.4 \mathrm{~Hz}$ ), 7.72 (s, 2H, H-3/4), 7.79 (s, 1H, H-1), 9.7 (s, 2H, H-13); ${ }^{13} \mathrm{C}$ NMR (DMSO $\delta 39.5$ ppm) 21.0 $\mathrm{CH}_{3}, 91.5 \mathrm{C}-7,115.6 \mathrm{C}-11,124.6 \mathrm{C}-4,125.5 \mathrm{C}-1,128.6 \mathrm{C}-10,132.3$ C-6, 131.7 C-9, 136.1 C-3, 139.9 C-2. 148.2 C-5, 157.9 C-12, 169.5 C-8; lrc H1 CH $/$ C-8/C3/C-5, H-3 CH$/$ C-5/C-1, H-4 C-2/C-6/C-7, H-10 C-7/C-10/C-12, H-11 C-9/C-11; NOESY CH 3 H-1/H-3, H-11 H-10/H-13, H-10 H-1, H-3 H-4.

\section{General method for preparation benzoic acid derivatives 13-14}

A mixture of phthalic anhydride, phenol and tetrachloroethane was slowly added of aluminum chloride with magnetic stirrer. When the production of hydrochloric acid finished, the mixture was heated at $120^{\circ} \mathrm{C}$ for twenty-four hours. At the end of the reaction the mixture was chilled with addition of ice and then filtered. The filtrate was digested in a solution of sodium hydroxide, and then filtered to remove the insoluble fraction. The soluble part was precipitate with hydrochloric acid and isolated though filtration. A fractionated crystallization conducted in acetone/petroleum ether gave two compounds:

2-(2-Hydroxy-benzoyl)-benzoic acid (13). Yield $22 \%$; mp 160-165 ${ }^{\circ} \mathrm{C}$; ${ }^{1} \mathrm{H}$ NMR (DMSO $\delta$ $2.6 \mathrm{ppm}) 6.85(\mathrm{~d}, 1 \mathrm{H}, \mathrm{H}-8, J=8.2 \mathrm{~Hz}), 7.05(\mathrm{t}, 1 \mathrm{H}, \mathrm{H}-6, J=8.0 \mathrm{~Hz}), 7.12(\mathrm{t}, 1 \mathrm{H}, \mathrm{H}-7, J=$ $8.2 \mathrm{~Hz}), 7.55(\mathrm{~d}, 1 \mathrm{H}, \mathrm{H}-4, J=8.0 \mathrm{~Hz}), 7.60(\mathrm{~d}, 1 \mathrm{H}, \mathrm{H}-5, J=7.8 \mathrm{~Hz}), 7.83(\mathrm{t}, 1 \mathrm{H}, \mathrm{H}-2, J=$ $7.4 \mathrm{~Hz}$ ), 7.95 (t, 1H, H-3, J= $7.6 \mathrm{~Hz}), 8.06$ (d, 1H, H-1, J= $7.4 \mathrm{~Hz}), 11.72$ (s, 1H, H-9), 13.15 (s, 1H, H-10).

2-(4-Hydroxy-benzoyl)-benzoic acid (14). Yield $16 \%$; mp 210-212 ${ }^{\circ} \mathrm{C} ;{ }^{1} \mathrm{H}$ NMR (DMSO $\delta$ $2.6 \mathrm{ppm}) 6.93$ (d, 2H, H-6, J = 7.8 Hz), 7.42 (dd, 1H, H-4, J=8.0, $1.0 \mathrm{~Hz}), 7.59$ (d, 2H, H-5, J= $7.8 \mathrm{~Hz}), 7.71$ (dt, 1H, H-2, J=7.4, $1.0 \mathrm{~Hz}$ ), 7.78 (dt, 1H, H-3, J=7.6, $1.2 \mathrm{~Hz}), 8.25$ (dd, 1H, H1, $J=7.4,1.2 \mathrm{~Hz}), 10.58$ (s, 1H, H-7), 13.15 (s, 1H, H-8).

3-(2-Chloro-phenylsulfanyl)-3-(4-hydroxy-phenyl)-3H-isobenzofuran-1-one (15). A mixture of 2-(4-hydroxy-benzoyl)benzoic acid (14) (2g, $8.2 \mathrm{mmol})$ and freshly distilled thionyl chloride $\left(5 \mathrm{ml}\right.$ ) was stirred at $80^{\circ} \mathrm{C}$ for $14 \mathrm{~h}$. After cooling, the excess of thionyl chloride was evaporated under vacuum; the crude was extracted repeatedly with toluene, the soluble fraction was dried and the new crude was dissolved in toluene. To the solution was then added with stirring 2chlorothiophenol $(8 \mathrm{mmol})$, dissolved in toluene. The reaction mixture was stirred at $40^{\circ} \mathrm{C}$ for 2 $\mathrm{h}$, cooled and the resultant precipitate was filtered and purified by flash-chromatography with chloroform/methanol (98/2 v.v). Yield $5.2 \%$; mp 122-125 ${ }^{\circ} \mathrm{C},{ }^{1} \mathrm{H}$ NMR (DMSO $\delta 2.6 \mathrm{ppm}$ ) $6.93(\mathrm{~d}, 1 \mathrm{H}, \mathrm{H}-6, J=8.8 \mathrm{~Hz}), 7.23(\mathrm{dt}, 1 \mathrm{H}, \mathrm{H}-8, J=7.5,1.0 \mathrm{~Hz}), 7.37$ (dt, 1H, H-9, $J=7.5$, $1.0 \mathrm{~Hz}$ ), 7.44 (dd, 1H, H-7 J = 7.6, 1.2 Hz), 7.47 (dd, 1H, H-10, J=7.6, $1.0 \mathrm{~Hz}), 7.63$ (t, 1H, H$3, J=7.8 \mathrm{~Hz}), 7.65(\mathrm{~d}, 2 \mathrm{H}, \mathrm{H}-5, J=8.8 \mathrm{~Hz}), 7.72(\mathrm{~d}, 1 \mathrm{H}, \mathrm{H}-4, J=8.0 \mathrm{~Hz}), 7.91(\mathrm{t}, 1 \mathrm{H}, \mathrm{H}-2, J=$ $8.0 \mathrm{~Hz}), 8.07$ (d, 1H, H-1, J=7.6 Hz), 9.93 (s, 1H, H-11). 
Enzymology. The synthesized compounds were screened for their activity and their specificity versus LcTS, EcTS and hTS. Compounds 8, 9 and 12 were tested as an isomeric mixture, compound $\mathbf{1 5}$ was tested as a racemic mixture. All the compounds showed an almost competitive inhibition pattern. The enzymes were purified as previously described. ${ }^{20-25}$

The $K_{i}$ values were obtained applying the known equation suitable for competitive inhibitors. ${ }^{26}$ All the measures were repeated at least three times and the experimental error is within the $20 \%$ of the average value. The maximum solubility is reported when a molecule does not show any inhibition activity at the solubility limit.

All the reagents were commercially available and at the highest purity grade. 6-R-5,10methylenetetrahydrofolate was kindly provided by EPROVA (Switzerland).

The enzymatic assays have been conducted with UV-Vis spectrophotometer Beckman DU 640. Enzyme kinetic experiments were conducted under standard conditions. ${ }^{3,27}$ Stock solutions of each inhibitor were prepared in DMSO. DMSO never exceeded $5 \%$ in the enzyme assay mixture, under this concentration enzyme activity was not affected (Costi and Soragni unpublished data). Assay were performed at room temperature in the standard assay buffer prepared with TES ( $N$-tris(hydroxymethyl) methyl-2-aminoethanesulfonic acid) $(50 \mathrm{mM})$ at $\mathrm{pH}$ 7.4, $\mathrm{MgCl}_{2}(25 \mathrm{mM})$, formaldehyde $(6.5 \mathrm{mM})$, EDTA (1 mM), and 2-mercaptoethanol $(75 \mathrm{mM})$; the concentration of mTHF was kept ten times the $\mathrm{K}_{\mathrm{m}}$ (respectively 7.7, 6.3 and $6.3 \mu \mathrm{M}$ for LcTS, EcTS and hTS); dUMP concentration was $120 \mu \mathrm{M}$. Enzyme activity was determined spectrophotometrically by steady-state kinetic analysis, following the increasing absorbance at $340 \mathrm{~nm}$ due to the oxidation reaction of 6-R-5-10-methylenetetrahydrofolate to dihydrofolate. The reaction was started by addition of dUMP.

\section{Acknowledgements}

The Authors acknowledge MIUR (Ministero Italiano Università e Ricerca), CIGS (Centro Interdipartimentale Grandi Strumenti), CICAIA (Centro interdipartimentale calcolo ) and Mrs Fabrizia Soragni for her excellent technical assistance.

\section{References}

1. Costi, M. P.; Ferrari S. Curr. Drug Targets 2001, 2, 135.

2. Shoichet, B. K.; Stroud, R. M.; Santi, D. V.; Kuntz, I. D.; Perry, K. M. Science 1993, 259, 1445.

3. Carreras, C. W.; Santi, D. V. Annu. Rev. Biochem. 1995, 64, 721.

4. Hardy, L. W.; Finer-Moore, J. S.; Montfort, W. R.; Jones, M. O.; Santi, D. V.; Stroud, R. M. Science 1987, 235, 448.

5. Perry, K. M.; Fauman, E. B.; Finer-Moore, J. S.; Montfort, W. R.; Maley, G. F.; Maley, F.; Stroud, R. M. Proteins 1990, 8, 315. 
6. Costi, M. P. Med. Res. Rev. 1998, 18, 21.

7. Costi, M. P.; Rinaldi, M.; Tondi, D.; Pecorari, P.; Barlocco, D.; Ghelli, S.; Stroud, R. M.; Santi, D. V.; Stout, T. J.; Musiu, C.; Marangiu, E. M.; Pani, A.; Congiu, D.; Loi, G. A.; La Colla, P. J. Med. Chem. 1999, 42, 2112.

8. Stout, T. J.; Tondi, D.; Rinaldi, M.; Barlocco, D.; Pecorari, P.; Santi, D. V.; Kuntz, I. D.; Stroud, R. M.; Shoichet, B. K.; Costi, M. P. Biochem. 1999, 38, 1607.

9. Tondi, D.; Slomezynska, U.; Costi, M. P.; Watterson, D. M.; Ghelli, S.; Shoichet, B. K. Chem. Biol. 1999, 6, 319.

10. Costi, M. P.; Tondi, D.; Rinaldi, M.; Barlocco, D.; Pecorari, P.; Soragni, F.; Venturelli, A.; Stroud, R. M. Bioch. Biophys. Acta 2002, 1587, 206.

11. Ghelli, S.; Rinaldi, M.; Barlocco, D.; Gelain, A.; Pecorari, P.; Tondi, D.; Rastelli, G.; Costi, M. P. Bioorg. Med. Chem. 2003, 11, 951.

12. Ferrari, S.; Costi, M. P.; Wade, R. C. Chem. Biol. 2003, 10, 1183.

13. Danenberg, P. V.; Malli, H.; Swenson, S. Semin. Oncol. 1999, $26,621$.

14. Newell, D. R. Semin. Oncol. 1999, 26(2 Supp 6), 74.

15. Ghelli, S.; Rastelli, G.; Barlocco, D.; Rinaldi, M.; Tondi, D.; Pecorari, P.; Costi, M. P. Bioorg. Med. Chem. 1996, 4, 1783.

16. Vezzali, F. Sintesi e valutazione biologica di derivati ftaleinici e naftaleinici o-sostituiti come inibitori della Timidilato Sintasi. Degree Thesis, A.A.1995-96. Università di Modena e Reggio Emilia.

17. Jones, F. N.; Hauser, C. R. J. Org. Chem. 1962, 27, 3364.

18. Canavet, J. C.; Guilloton, O. Bull. Soc. Chim. Fr. 1981, 3-4, 96.

19. Chiericatti, G. Studio degli equilibri in soluzione di derivati ftaleinici e naftaleinici, inibitori della Timidilato Sintasi, mediante spettroscopia UV-VIS. Degree Thesis, A.A.1995-96. Università di Modena e Reggio Emilia.

20. Maley, G. F.; Maley, F. J. Biol. Chem. 1988, 263, 7620.

21. Climie, S.; Santi, D. V. Proc. Natl. Acad. Sci. USA 1990, 87, 633.

22. Davisson, V. J.; Sirawaraporn, W.; Santi, D. V. J. Biol. Chem. 1989, 264, 9145.

23. Davisson, V. J.; Sirawaraporn, W.; Santi, D. V. J. Biol. Chem. 1994, 269, 30740.

24. Kealey, J. T.; Santi, D. V. Prot. Expr. Purif. 1992, 4, 380.

25. Hanahan, D. J. Mol. Biol. 1983, 166, 557.

26. Segel, I. H. Enzyme kinetics. Behaviour and analysis of rapid equilibrium and steady-state enzyme systems, John Wiley and Sons Inc, New York, 1975, 150.

27. Pogolotti, A. L. Jr; Danenberg, P. V.; Santi, D. V. J. Med. Chem. 1986, 29, 478. 